\title{
Demographic Data Analysis And Educational System Planning For Primary Education Delivery In Abia State, Nigeria.
}

\author{
Kenneth K. Obasi, Ph.D \\ Department Of Educational Management \\ University Of Port Harcourt
}

\begin{abstract}
The determination of the level of demographic analysis and educational system planning in the provision of primary education in Abia State, Nigeria was the thrust of this study. The study adopted the descriptive survey design. All the senior staff of the Ministry of Education and the Universal Basic Education Board constituted the population and the respondents. They were 59 in number. The instrument for the generation of data were questionnaire and structured interview. The title of the questionnaire was Demographic Data Analysis and Education System Planning for the provision of Primary Education Questionnaire (DDAESPPPEQ). The items of the instrument were structured based on the four point modified Likert response mode. The data were analyzed with Mean, standard deviation and t-test of difference. The findings of the study include the following: inadequate policy provisions and administrative strategies to ensure effective demographic data collection, analysis and utilization, poor synergistic relationship between the Ministry of Education, UBE Board and the agencies responsible for the generation of demographic data and poor funding. The study therefore recommended among other things that there should be comprehensive policy provision to ensure effective demographic data collection, analysis and utilization, more robust administrative strategies should be adopted for data collection, analysis and utilization and a more comprehensive synergy between the Ministry of Education, UBE Board and demographic data agencies.
\end{abstract}

\section{INTRODUCTION}

Every child, irrespective of his or her birth circumstances, has the latent capacity to learn and be developed to be an active agent of socio-economic development. Education is one veritable instrument that can activate and transform those potentials so as to raise the productive capacity of the individual. The Latin root of education which is 'Educere', which means 'to lead forth' or 'to come out' describes the basic function of education. Education therefore, seeks to actualize and develop those innate potentials in the individual human person and make the best out of him or her. Good in National Council of Educational Research and Training (2014), articulated education as the aggregate of all the processes by which a person's abilities, attitudes and other forms of behaviour of practical values of the society are developed so as to enable the individual obtain social competence and optimum development.

Ipso facto, education has been globally recognized as a fundamental right through the United Nations 1948 Universal Declaration of which Nigeria is a signatory. This historic declaration provided the platform for series of international conventions and Declarations to ensure that the affiliate member countries are practically committed to this cause. One of such was 1990 Jomtien Declaration of Education for all (EFA). UNESCO has been at the vanguard of this noble cause by assisting member nations through the provision of human and material resources, and capacity building and the provision of technical assistance. In her Millennium Report, UNESCO (2010) emphatically stated that education is the key to the new global economy, from primary school on up to life-long learning. It is at the center of development, social progress and human freedom. It went further to state that basic education has always been the key to 
freedom from subjugation, fear and want. Education is an effective weapon to fight poverty. It saves lives and gives people the opportunity to improve their lives. It gives people a voice and increases a nation's productivity and competitiveness and also an instrument for social and political progress.

It is on this premise that there is a global clamour for basic education be made free and accessible so that every child of school age, irrespective of the gender, creed or socio-economic background should have unhindered access to basic education as the minimum. The scope of basic education, though subjective among nations, is meant to equip every individual child of school age to transit to the next level of education and the world of work. Basic education therefore, refers to the entire range of educational activities that take place in various settings, formal and informal, that aims to meet basic learning needs. Hence Universal basic education is regarded as a priority for developing countries and it is the focus of the Education For All (EFA) movement led by UNESCO (Wikipedia, 2013). The importance of basic education in human development was also highlighted by Business Line (2011). It remarked that people lacking basic education, acquired usually at the primary and lower secondary school, find new skills required for decent jobs a difficult task. The limited reach of skills development programme not only affects the potential for socio-economic growth but also makes the transition from school to work difficult.

As earlier stated, the scope of basic education differs from one country to another. Some countries limit it to the primary level, some extend it to junior secondary (like Nigeria) and there are countries that have it up to senior secondary. In all these sceneries however, primary education is critical, fundamental and foundational and it is the concern of this study. Primary education provides the foundational blocks upon which the other levels of education stand. The National Policy on Education of the Federal Republic of Nigeria (2014) clearly spelt out the goals of primary education to include laying sound foundation for scientific and reflective thinking. Also it is meant to give citizenship education as a basis for effective participation in and contribution to the life of the society. Another goal of primary education is to give the child opportunities to develop manipulative skills that will enable him or her function effectively in the society, and also provide the child with basic tools for further educational advancement.

These goals are noble and promising if effectively implemented. Imagine a child, who for no fault of his/her is denied this golden opportunity of life. It will be a tragedy, an attack on the dignity of the human person and a colossal waste of potential manpower for the society.

In the same vein, Hallak (1991) remarked that illiteracy and lack of access to education often go hand-in-hand with the lack of participation in, and access to other social services ... and to employment and an adequate income, securing only poverty and marginality for certain groups of the population.

To that extent, Philips (1975) pointed out that the reason for special concern with the first or basic level of education is not only that it is the level which has the role of covering the whole population as their human right, for most of the people in the world, basic education is, and will be for a long time, the only education experience. He went further to say that when a part of mankind continue growing up and entering adult life without a minimum of basic education, economically, it means a great loss of human resource potential; socially, it means tension between the educational privileged and the deprived; and for the individual, it means loss of dignity and of opportunity. 
From the foregoing, it is obvious that primary education which is at the heart of basic education deserves to be at the front burner of any educational system. For instance, the goals of primary education as outlined by the Nigeria National Policy on Education will remain elusive if the education system fails to give it adequate attention through proper planning and implementation. Educational planning is strategic and operational process of articulating the plans, resources (human and material) to ensure the effective and efficient realization of stated goals and objectives. It is a management function and tool that tries to understand the present educational challenges, weakness and strength in order to project into the future conscious of environmental dynamism so that the education system remains effective, efficient, relevant, functional and competitive. Educational planning bridges the gap between the present and the future of a society's education system in response to the present and future educational needs occasioned by environmental changes. It devices strategies and actions in the coordination and optimal utilization of both human and material resources for the development of a society's education system (Obasi \& Ohia, 2017).

Educational planning is the life wire of any education system. It is not a one-shot activity, it is continuous and dynamic so as to effectively deal with the environmental variables that are in constant flux. The planning of education takes into cognizance the different facts of the society (environmental variables) because it is aimed at using education as a potent instrument for the society. Educational planning is therefore a process that is dynamic, determined and conditioned by the exigencies of the time (Obasi, 2012).

One of the most important ingredients in this educational planning process is demographic data. Education is planned for the society and the information about the people for whom education is planned is critical. Hence, the population information significantly provides the direction, magnitude and dynamism in the provision of education. Demographic basically deals with a given population both in its static and dynamic aspects, it deals with both the structure and behaviour of a population as it changes overtime. Demographic analysis involves the study of the components of population variations and change Static demographic analysis deals with the current situation of the population, the structure or composition. It also deals with the dynamic aspect which aims at the trend or movement of the population which depends on some demographic factors as birth rates, death rates (Mohanty, 2015). In planning education for a given population or demographical entity, the sufficient knowledge of the structure and behaviour of the population is therefore imperative.

Accurate demographic data analysis has a significant relationship with educational provision equity, access and rational utilization of resources. To function effectively, educational planners need to have adequate knowledge about the sizes of client groups, their structure and the dynamics of population changes among various client systems. The accurate knowledge of the size of school-age population will assist planners and subsequently, policy makers to know the extent educational services can be provided free by public authorities (Akinwumiji \& Owolabi, 2002).

Demographic data provides the platform and rationale for the development of educational plans. Furthermore, proper demographic data analysis, to a large extent, determines the potential demand for education and also the nature and type of education to be provided. The purpose of the demographic analysis is to technically isolate the component of demographic patterns by dividing a population into relatively homogeneous sub-groups like age and sex. This analysis helps planners to measure the relative size of the school-age population which is the foundation and the point of departure of any educational policy. It also helps in 
determining the cost of education and the choice of types, sizes and locations of schools (Chau, 2003).

The need for proper demographic data analysis and utilization is more pressing in the provision of primary education when it is free and compulsory. Nigeria is a case in point. The global quest for education for all children of school age requires a great deal of commitment on the part of the government and her agencies to ensure that the programme is a success and that no child is left behind. One of such strategies is adequate demographic data analysis and utilization. It is on this premise that Bella and Belkachla (2010) cautioned that in countries where high population growth often goes hand-in-hand with low enrolment levels, demographic trends-which can have a negative impact on the state of education-represent a factor that absolutely must be taken into account in any strategy aimed at achieving Universal Primary Education (UPE).

To corroborate this position, Hallak (1977) when he stated that demographic data are the basis of any projection of enrolment figures, particularly in the case of primary schooling. Demographic data are seldom available for individual school districts. Moreover, in the projection of demographic data, a number of corrections have to be made to take stock of noncoincident boundaries of administrative and school districts and population movements.

The positive relationship between demographic data and education access and quality places a great burden on policy makers and educational planners in ensuring that all children of school age have unhindered access to quality basic education. To that extent, Lewin (1997) pointed out that population growth remains the single most important factor in determining the long term growth of demand for educational services. It is intimately linked with the problems of providing adequate resources to meet expanded demand. Hence, countries where the growth rate of the school age group exceeds the rate of economic growth, it is clear that, all things being equal, larger proportions of central government expenditure will have to be allocated to maintain current enrolment ratios.

\section{The Problem}

Primary education is the fundamental building block for the right to education and the foundational base of any basic education. Universal Basic Education which is a strategic national programme to ensure that all children of school age, irrespective of the varying circumstances of their birth have unhindered access to quality education, to prepare them for both higher education and the world of work. However, after more than one and half decades the programme effectively took off, there are many children of school age who are out of school. Some of them either have not yet been in school or dropped out, thereby exacerbating the level of child labour, social vices and economic burden on both the families and the society in general, majorly due to poor human development. Some scholars have even remarked that primary education has been inadvertently cast as Cinderella. As the population continues to grow, more cases of out-of-school children are recorded. The concern of this study is therefore, on the level of demographic data analysis and utilization to ensure that all primary school age children are adequately provided for.

\section{Aim and Objectives of the study}

The aim of the study was to investigate the level of demographic data provision and utilization in the provision of primary education in Abia State. Specifically, the objectives of the study was to determine the following:

- The policy provisions on demographic data for primary education provision

- The sources of demographic data for the provision of primary education 
- The strategies adopted for effective demographic data collection and analysis

- The challenges militating against effective demographic data collection, analysis and utilization

\section{Research Questions}

- What are the policy provisions on demographic data for primary education provision in Abia State?

- What are the sources of demographic data for the provision of primary education in Abia State?

- What are the strategies adopted for effective demographic data collection and analysis in Abia State?

- What are the challenges militating against effective demographic data collection, analysis and utilization in the provision of primary education in Abia State?

\section{Hypotheses}

- There is no significant difference between the staff of the Ministry of Education and the staff of the UBE Board with respect to the policy provisions on demographic data for the provision of primary education in Abia State.

- There is no significant difference between the staff of UBE Board and the Ministry of Education with respect to the sources of demographic data for the provision of primary education in Abia State.

- There is no significant difference between the staff of UBE Board and the Ministry of Education with reference to the strategies adopted for effective demographic data collection and analysis in Abia State.

- There is no significant difference between the staff of UBE Board and the Ministry of Education with respect to the challenges militating against effective demographic data collection, analysis and utilization in the provision of primary education in Abia State.

\section{METHODOLOGY}

The study adopted the descriptive Survey design. The population was all the senior staff of the Universal Basic Education Board and the Ministry of Education of Abia State. They were 59 in number. The instruments for the study were a researcher structured questionnaire titled DEMOGRAPHIC DATA ANALYSIS AND EDUCATIONAL SYSTEM PLANNING FOR PRIMARY EDUCATION PROVISION QUESTIONNAIRE (DDAESPPEPQ) and structured interview. The questionnaire was structured based on the four point modified Likert Scale of Strongly Agree, Agree, Disagree and Strongly Disagree. Mean, Standard Deviation, t-test of Difference were used for data analysis. The instrument was properly validated and the reliability was established using Cronbach Alpha method that gave an index of 0.81. the data generated were analyzed using mean, standard deviation and t-test of difference.

\section{Data Analysis}

Research Question 1: What are the policy provisions on demographic data for primary education provision? 
Table1: Mean and standard deviation of the responses on the policy provisions on demographic data for primary education provision.

\begin{tabular}{|c|c|c|c|c|c|c|c|c|}
\hline \multirow[t]{2}{*}{$\mathbf{S} / \mathbf{N}$} & & \multicolumn{2}{|c|}{$\begin{array}{l}\text { MINISTRY } \\
\text { STAFF }\end{array}$} & \multicolumn{2}{|c|}{ UBE STAFF } & \multicolumn{2}{|c|}{ AVERAGE } & \multirow[t]{2}{*}{ REMARKS } \\
\hline & & MEAN & SD & MEAN & SD & MEAN & SD & \\
\hline 1 & $\begin{array}{l}\text { The policy provision on } \\
\text { demographic data for primary } \\
\text { education }\end{array}$ & & & & & & & \\
\hline $\mathrm{a}$ & $\begin{array}{l}\text { There are policies on the } \\
\text { sources of the data }\end{array}$ & 3.10 & 0.94 & 3.02 & 0.98 & 3.06 & 0.96 & Accepted \\
\hline $\mathrm{b}$ & $\begin{array}{l}\text { There are policies on the } \\
\text { frequency of the data } \\
\text { collection }\end{array}$ & 3.00 & 1.03 & 3.12 & 1.02 & 3.06 & 1.03 & Accepted \\
\hline $\mathrm{c}$ & $\begin{array}{l}\text { There are policies on the data } \\
\text { analysis variables }\end{array}$ & 1.85 & 0.89 & 2.02 & 1.05 & 1.94 & 0.97 & Rejected \\
\hline $\mathrm{d}$ & $\begin{array}{l}\text { There are policies on the } \\
\text { procedures for data collection, } \\
\text { analysis and utilization }\end{array}$ & 2.06 & 1.01 & 2.67 & 1.07 & 2.37 & 1.04 & Rejected \\
\hline
\end{tabular}

Table 1 above shows that there are policy provisions on items a and $\mathrm{b}$ with mean values of 3.10 and 3.00 for the Ministry staff and 3.06 and 3.06 for the UBE staff are above the criterion mean of 2.50. However, the items $\mathrm{c}$ and $\mathrm{d}$ with mean values below the criterion mean are not provided for in the policy.

Research Question 2: What are the sources of demographic data for the provision of primary education?

Table 2: mean and standard deviation of the responses on the sources of demographic data for the provision of primary education.

\begin{tabular}{|l|l|l|l|l|l|l|l|l|}
\hline 2 & $\begin{array}{l}\text { The following are the sources of } \\
\text { demographic data for primary } \\
\text { education provision }\end{array}$ & & & & & & & \\
\hline $\mathrm{a}$ & Census Bureau & 2.94 & 1.02 & 2.95 & 1.66 & 2.95 & 1.34 & Accepted \\
\hline $\mathrm{b}$ & National Population Commission & 2.90 & 1.07 & 2.83 & 1.06 & 2.87 & 1.07 & Accepted \\
\hline $\mathrm{c}$ & Demographic Institute & 2.33 & 1.07 & 2.02 & 0.92 & 2.42 & 1.00 & Rejected \\
\hline $\mathrm{d}$ & $\begin{array}{l}\text { Population Division of the Ministry } \\
\text { of Internal Affairs }\end{array}$ & 1.85 & 0.94 & 1.83 & 0.99 & 1.84 & 0.97 & Rejected \\
\hline
\end{tabular}

Table 2 shows that items a and b of 2.94 and 2.90 for the Ministry staff and 2.952 .87 for the UBE staff were accepted to be the sources of data because their mean values are above the criterion mean of 2.50, while the other two items of $\mathrm{c}$ and $\mathrm{d}$ with mean values below the criterion mean are rejected.

Research Question 3: What are the strategies adopted for effective demographic data collection and analysis? 
Table 3: Mean and standard deviation of the responses on the strategies adopted for effective demographic data collection and analysis

\begin{tabular}{|c|c|c|c|c|c|c|c|c|}
\hline 3 & $\begin{array}{l}\text { The following strategies are } \\
\text { adopted for effective demographic } \\
\text { data collection and analysis }\end{array}$ & & & & & & & \\
\hline $\mathrm{a}$ & $\begin{array}{l}\text { The UBE Board has statistics } \\
\text { experts in the Census Bureau } \\
\text { office in the National Population } \\
\text { Commission, Population Division } \\
\text { of the Ministry of Internal Affairs }\end{array}$ & 2.97 & 0.96 & 2.86 & 1.12 & 2.92 & 1.04 & Accepted \\
\hline $\mathrm{b}$ & $\begin{array}{l}\text { The Ministry of Education has } \\
\text { statistics experts in the Census } \\
\text { Bureau office in the National } \\
\text { Population } \\
\text { Population Division of the Ministry } \\
\text { of Internal Affairs }\end{array}$ & 3.28 & 1.99 & 2.83 & 1.17 & 2.83 & 1.58 & Accepted \\
\hline $\mathrm{c}$ & $\begin{array}{l}\text { The UBE Board regularly liaises } \\
\text { with all the different population } \\
\text { agencies for effective synergy }\end{array}$ & 2.17 & 1.17 & 2.02 & 0.92 & 2.10 & 1.05 & Rejected \\
\hline $\mathrm{d}$ & $\begin{array}{l}\text { The Ministry of Education } \\
\text { regularly liaises with all the } \\
\text { different population agencies for } \\
\text { effective synergy }\end{array}$ & 2.01 & 1.22 & 1.83 & 0.99 & 1.92 & 1.11 & Rejected \\
\hline
\end{tabular}

Table 3 reveals that items a and $b$ which have mean values of 2.97 and 3.28 for the Ministry staff and 2.92 and 2.83 for the UBE staff are above the criterion mean of 2.50 are accepted. However, items $c$ and $d$ are rejected because their mean values for the responses of the two respondents are below the criterion mean.

Research Question 4: What are the challenges militating against effective demographic data collection, analysis and utilization in the provision of primary education?

Table 4: Mean and standard deviation responses on the challenges militating against demographic data collection, analysis and utilization in the provision of primary education.

\begin{tabular}{|c|c|c|c|c|c|c|c|c|}
\hline 4 & $\begin{array}{l}\text { The following challenges militate } \\
\text { against effective demographic data } \\
\text { collection, analysis and utilization }\end{array}$ & & & & & & & \\
\hline $\mathrm{a}$ & $\begin{array}{l}\text { Ineffective policy } \\
\text { formulation/implementation }\end{array}$ & 3.24 & 0.81 & 2.90 & 1.03 & 3.07 & 0.92 & Accepted \\
\hline $\mathrm{b}$ & Inadequate qualified data analysts & 2.57 & 1.08 & 2.89 & 0.89 & 2.53 & 0.99 & Accepted \\
\hline c & $\begin{array}{l}\text { Poor synergy between the } \\
\text { Ministry of Education and the } \\
\text { relevant population agencies }\end{array}$ & 3.28 & 1.99 & 2.02 & 1.05 & 2.65 & 1.52 & Accepted \\
\hline $\mathrm{d}$ & $\begin{array}{l}\text { Poor synergy between the UBE } \\
\text { Board and the relevant population } \\
\text { agencies }\end{array}$ & 3.04 & 0.96 & 3.12 & 1.02 & 3.08 & 0.99 & Accepted \\
\hline $\mathrm{e}$ & $\begin{array}{l}\text { Dearth of quality demographic } \\
\text { data }\end{array}$ & 2.89 & 1.03 & 2.95 & 1.66 & 2.92 & 1.35 & Accepted \\
\hline $\mathrm{F}$ & $\begin{array}{l}\text { Delay in the release of } \\
\text { demographic data }\end{array}$ & 2.87 & 1.07 & 2.83 & 1.77 & 2.85 & 1.42 & Accepted \\
\hline G & Poor funding & 2.94 & 1.01 & 3.02 & 0.99 & 2.98 & 1.00 & Accepted \\
\hline
\end{tabular}


Table 4 shows that all the identified challenges militating against demographic data collection, analysis and utilization in the provision of primary education are accepted. This because all the items have mean values 3.24,2.57,3.28,3.04,2.89,2.87, 2.94 for the Ministry staff and 3.07, 2.53, $2.65,3.08,2.92,2.85$ and 2.98 for the UBE staff are above the criterion mean of 2.50

\section{Test of Hypotheses}

Ho1: There is no significant difference between the staff of the Ministry of Education and the staff of the UBE Board with respect to the policy provisions on demographic data for the provision of primary education in Abia State.

Table 5: t-test of difference on the responses of the staff of the Ministry of Education and the staff of the UBE Board with respect to the policy provisions on demographic data for the provision of primary education in Abia State

\begin{tabular}{|l|l|l|l|l|l|l|l|l|l|}
\hline $\mathbf{s} / \mathbf{n}$ & Category & $\mathbf{N}$ & $\mathbf{X}$ & SD & $\mathbf{d f}$ & z-cal & z-crit & $\begin{array}{l}\text { Sign } \\
\text { level }\end{array}$ & Remarks \\
\hline 1 & Ministry Staff & 31 & 2.50 & 0.99 & 57 & -1.65 & 1.96 & 0.05 & $\begin{array}{l}\text { Not } \\
\text { significant }\end{array}$ \\
\hline 2 & UBE Staff & 28 & 2.71 & 1.03 & & & & &
\end{tabular}

The table shows that the calculated z-value of 1.65 is less than the critical z-value of 1.96 . The study therefore failed to reject the hypothesis.

Ho2: There is no significant difference on the responses of the staff of the Ministry of Education and the staff of the UBE Board with respect to the sources of demographic data for the provision of primary education in Abia State.

Table 6: t-test of difference on the responses of the staff of the Ministry of Education and the staff of the UBE Board with respect to the sources of demographic data for the provision of primary education in Abia State.

\begin{tabular}{|l|l|l|l|l|l|l|l|l|l|}
\hline $\mathbf{S} / \mathbf{n}$ & Category & $\mathbf{N}$ & $\mathbf{X}$ & SD & $\mathbf{d f}$ & z-cal & z-crit & $\begin{array}{l}\text { Sign } \\
\text { level }\end{array}$ & Remarks \\
\hline 1 & Ministry Staff & 31 & 2.63 & 1.03 & 57 & 1.87 & 1.96 & 0.05 & $\begin{array}{l}\text { Not } \\
\text { significant }\end{array}$ \\
\hline 2 & UBE Staff & 28 & 2.41 & 1.16 & & & & &
\end{tabular}

The table above shows that the calculated z-value of 1.87 is less than the critical z-value which is 1.96 . Hence, the study upheld the hypothesis.

Ho3: There is no significant difference between the responses of the staff of the Ministry of Education and the staff of the UBE Board with respect to the strategies adopted for effective demographic data collection, analysis and utilization in the provision of primary education in Abia State.

Table 7: t-test of difference on the responses of the staff of the Ministry of Education and the staff of the UBE Board with respect to the strategies adopted for effective demographic data collection, analysis and utilization for the provision of primary education in Abia State.

\begin{tabular}{|l|l|l|l|l|l|l|l|l|l|}
\hline $\mathbf{S} / \mathbf{n}$ & Category & $\mathbf{N}$ & $\mathbf{X}$ & SD & $\mathbf{d f}$ & $\mathbf{z}$-cal & z-crit & $\begin{array}{l}\text { Sign } \\
\text { level }\end{array}$ & Remarks \\
\hline 1 & Ministry Staff & 31 & 2.61 & 1.34 & 57 & 1.62 & 1.96 & 0.05 & $\begin{array}{l}\text { Not } \\
\text { significant }\end{array}$ \\
\hline 2 & UBE Staff & 28 & 2.39 & 1.05 & & & & & \\
\hline
\end{tabular}

Table 7 indicates that the calculated z-value which is 1.62 is less than the critical value of 1.96 . As a result of this, the study failed to reject the hypothesis. 
Ho4: There is no significant difference between the responses of the staff of the Ministry of Education and the staff of the UBE Board with respect to the challenges militating against the effective demographic data collection, analysis and utilization in the provision of primary education in Abia State

Table 8: t-test of difference on the responses of the staff of the Ministry of Education and the UBE Board with respect to the challenges militating against the effective demographic data collection, analysis and utilization in the provision of primary education in Abia state

\begin{tabular}{|l|l|l|l|l|l|l|l|l|l|}
\hline $\mathbf{S} / \mathbf{n}$ & Category & $\mathbf{N}$ & $\mathbf{X}$ & SD & df & z-cal & z-crit & $\begin{array}{l}\text { Sign } \\
\text { level }\end{array}$ & Remarks \\
\hline 1 & Ministry Staff & 31 & 2.92 & 1.14 & 57 & 1.26 & 1.96 & 0.05 & $\begin{array}{l}\text { Not } \\
\text { significant }\end{array}$ \\
\hline 2 & UBE Staff & 28 & 2.82 & 1.20 & & & & & \\
\hline
\end{tabular}

Table 8 shows that the calculated z-value of 1.26 is less than the critical z-value of 1.96 . Hence, the study upheld the hypothesis.

\section{DISCUSSION OF FINDINGS}

The study revealed that though there are some policy provisions on demographic data for the provision of primary education, they are not adequate to address some critical areas. This gave credence to the remark of Custer, King, Atinc, Read and Sethi (2018). They stated that while continued investments in data creation and management are necessary, the ultimate value of information is not in its production, but its use. Herein lies one of the biggest challenges of translating information into actionable insights: those that produce education data are often far removed from those that make crucial decisions about education policies, programmes and investments. With limited insights on what decision makers use and need, the likelihood of disconnect between supply and demand is high.

The findings of the study showed that demographic data are basically sourced from the National Population Commission and the Census Bureau. The rationale behind this position is to avoid discrepancies that might arise from multiple sources of data. This therefore corroborates the submission of Mohanty (2015) that the utilization of data from multiple sources can give rise to inconsistencies and various perceptions of a countrys progress towards the goal of achieving Universal Primary Education (UPE). While it may not be easy to determine which are more accurate than others, it is important to shed light on the nature and scale of the problems facing statisticians in education.

It was also revealed by the study that the administrative strategies adopted for effective demographic data collection, analysis and utilization are very inadequate. This situation obviously will not augur well with this course, hence, UNSCD (2014) pointed out that direct demographic techniques require reliable and comprehensive information on population, births, deaths... usually from censuses and registration systems. However, in most parts of the world, vital registration is incomplete and censuses usually suffer underenumeration and other defects. Many of the standard direct methods of demographic estimation that can be used in a "perfect world" cannot be applied successfully to the majority of the world population. In the same vein, Chau (2003) observed that in countries where statistics are reliable, where censuses are taken regularly and carefully, and vital statistics units operate efficiently, population data are presented with all the necessary accuracy and precision, and the population projections based on such data have every chance of being accurate as well. 
The study identified some challenges that hinder effective demographic data collection, analysis and utilization. They include dearth of qualified data analysts, poor synergy between data providers and users, dearth of quality demographic data, delay in the release of data and poor funding. Udoh (2017) therefore identified some of the factors that account for inaccurate data in Nigeria which include inadequate and obsolete technology, poor infrastructure, poor funding, shortage of qualified manpower, and ineffective supervision. Furthermore, he observed that most offices lack basic equipment like computer sets. Hence, files are still kept in shelves and cabinet which could be misplaced, lost or damaged. To that extent, Chau (2003) pointed out that census no longer consist in merely counting the population, they now provide the opportunity to obtain a wide variety of information. They have thus become more and more complex operations, and an increasingly specialized and numerous staff are needed to carry them out. Moreover, owing to the size of the operation, and owing to the number and number and variety of the statistics to be compiled, it takes some time to process census data. The problem is that in population analysis, as in other fields, statistical data lose some of their value if they are not made available quickly.

\section{CONCLUSION}

On the strength of the findings, the study therefore concluded that though there are some policy provisions and administrative strategies adopted to ensure effective demographic data collection, analysis and utilization in the provision of primary education, there are a lot of inadequacies and challenges that need to be aggressively addressed.

\section{RECOMMENDATIONS}

Based on the findings, the following recommendations were made:

- The government and the relevant agencies should provide a more comprehensive policy to ensure effective demographic data collection, analysis and utilization in the provision of primary education.

- The Ministry of education and the UBE Board should develop more robust strategies in the collection, analysis and utilization of demographic data.

- The Ministry of Education and the UBE Board should develop a plan for the training of more personnel statisticians and data analysists in their employment

- There should be a comprehensive framework to ensure a synergistic relationship between the Ministry of Education, UBE Board and the agencies responsible for the demographic generation.

- The agencies responsible for data generation and analysis should be adequately funded.

\section{References}

Bella, N \& Belkachla, S. (2010). Impact of demographic trends on the achievement of the Millenium Development Goal of Universal Primary Education. Paris: UNESCO

Chau, T. (2003). Demographic aspects of educational planning. Paris: International Institute for Educational Planning

Custer,S., King, E. M., Atinc, T. M., Read, L. \& Sethi, T. (2018). Toward data-driven education systems: insights into using information to measure results and manage change. Brookings: Center for Universal Education

Hallak, J. (1991). Education for all: high expectations or false hopes? Paris: UNESCO

Hallak, J. (1977). Planning the location of schools: an instrument of educational policy. Paris: UNESCO: International Institute for Educational Planning

Lewis, K. M. (1997). Educational and developments: the issues and the evidence. Education Research. 6,(61) pp.

Mohanty, N. K. (2015). Demographic aspects of educational planning. Retrieved from http://www.educationforallinindia.com/use-of-demographic-modules-in 
National Council of Educational Research and Development (2014). Basics in education. New Delhi: NCERT

Obasi, k. K. (2012). The concept of planning. In J. D. Asodike, L. E. S. Kaegon, O. E. Oluwolu \& N. Amadike (Eds). Educational planning and supervision: an introductory text. Port Harcourt: Infomedia

Obasi, K. K. \& Ohia, A. N. (2017). Educational planning: the basics. In K. Okrosayo-Orubite, C. N. Olele, N. M. Abraham \& G. Adekola(Eds). Introduction to education. Port Harcourt: University of Port Harcourt Press

Udoh, U. (2017). Planning Nigerian education: problems, issues and Proposed solutions. Retrieved from: https://www.researchGate.net/publications/316682135

UNSD (2014). Overview of demographic concepts and methods. Paris: UNESCO 